\title{
The Global Museum and the Orbit of the Solomon R. Guggenheim Museum New York
}

\author{
Susan Ostling, Griffith University, Queensland, Australia
}

\begin{abstract}
Entering general discourse is the expression the 'Bilbao effect', referring to urban renewal spurred on through high-profile culture. Within its first year of opening, the Guggenheim Museum Bilbao with 1.3million visitors, had paid for its building costs and the city had become alive with the pulse of economic growth and development. Its success prompted requests to build Guggenheim 'branches' in dozens of other locations. The vision for a world wide network of museums, coordinated from New York was the brainchild of the Director of the Guggenheim Foundation, Thomas Krens. It was initiated as a means to raise funds for the Guggenheim by capitalising on its greatest assets -its name, reputation and art collection. Kren's driving ambition to expand the Guggenheim into a brand, critics say has instead stretched resources, prompted the development of decidedly 'commercial' exhibitions and tarnished the reputation of a great art collection. In this paper I plan to highlight areas of contention in the global reach of the the Guggenheim New York, by discussing the creation of its museum satellites in Bilbao, Berlin, La Vegas and to be completed in 2011, Abu Dhabi. The main focus of the discussion will be on the Guggenheim Museum Bilbao where the tensions between the global and the local are particularly apparent.
\end{abstract}

Keywords: Global Predicaments, Guggenheim Museum, Guggenheim Bilbao, Museums

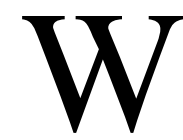

ITH WORLDWIDE UNPRECEDENTED growth in new art museums and with museums increasingly taking 'a central position in the institutional mediation of culture' (Rectanus 2002, p.171), art museums find themselves at the forefront in the interface of art and globalization. Art's perceived abilities to cross borders and hold powers of universal communication, ${ }^{1}$ has made it a ready player in international diplomacy. On the other hand, the reconceptualization of the art museum over the last twenty years has identified the importance of understanding the specifics of the local (regional, state, national) in generating audiences. Through identifying 'differentiated audiences' and 'new voices' there is recognition that there are different narratives, contexts and histories unfolding from art (Hooper-Greenhill, 2004, pp.5701). Circling models of the global museum then, is the tension between claims of art's universality and the increasing recognition of the importance of specificity in unravelling the relevance of contemporary art. $^{2}$

In this paper I plan to highlight areas of contention in the global reach of the first multi-national museum the Solomon R. Guggenheim New York, by discussing the creation of its museum satellites in Bilbao, Berlin, La Vegas and to be completed in 2011, Abu Dhabi. The main focus of the discussion will be on the Guggenheim Museum Bilbao where the tensions between the global and the local are particularly apparent.

Gayatri Spivak's overview of the concept of globalization as both a repetition and a rupture is valuable. As she says: 'The more one claims globalization to be a rupture, the more one is unable to see the repetition' (2007). Repetition abounds in the Guggenheim global project. Critics describe it as another form of cultural imperialism (Newhouse 2006, p.259) or the latest manifestation of the movement from centres of prestige to centres of wealth (Taylor 2007). Thomas Krens Director of the Solomon R. Guggenheim Foundation said in 2006:

I wonder how much we actually do that is different from other institutions. I mean for example, the major museums in the world develop projects together. They exchange projects all

\footnotetext{
1 'We believe the best vehicle for crossing borders is art. And this region is in need of such artistic initiatives.' Mubarek Muhairi, The Director General of the Abu Dhabi Tourist Authority, cited in Hassan Fattah, 1 February 2007, viewed 9 February 2007, www.nytimes.com/2007/02/01 arts /design/01 isla.html?ei=...

'It is with keen sense of historical precedent and with an abiding commitment to cultural exchange as a bridge to international understanding that the Guggenheim Foundation enters into this agreement to establish a Guggenheim museum in Abu Dhabi.' William Mach, Chairman of the Solomon R. Guggenheim Foundation, viewed 10 January 2007 www.guggenheim.org/press_releases/release_159.html

2 'As a medium of global participation and awareness, contemporary art claims to be universal, but it simultaneously presupposes local roots, alternative genealogies and plural modernities.' Conference overview International Research Center for Cultural Studies, Vienna, 25-27 January 2007, viewed 18 February 2007, www.ifk.ac.at/media.php
}

THE INTERNATIONAL JOURNAL OF THE HUMANITIES VOLUME 5, 2007

http://www.Humanities-Journal.com, ISSN 1447-9508

(C) Common Ground, Susan Ostling, All Rights Reserved, Permissions: cg-support@commongroundpublishing.com 
the time.' (Charlie Rose Show interview airdate 3 January 2006).

However, to see the Guggenheim project as only the latest instance of exchange between nations of wealth and nations of prestige, or, as simply an extension of collaboration between museums to share collections of art for exhibition, is to miss much. In particular, the Guggenheim's pursuit of a business model of expansion and income generation and its pursuit of economies of scale and brand name selling, marks a rupture, even from the way that museums have become increasingly linked to business structures in their scramble for corporate sponsorship.

Alan Wallach (2003, pp.105-6), identifies the difference in the nature of support for museums in the US prior to the 1960s by wealthy individuals and financiers, and the post 1960s rise of corporate sponsors, drawn into museums initially to underwrite the 'new scale of operations' of 'the blockbusters' (ibid., p.106). The pre-1960s patrons generally donated their collections of art (and often funded the space to exhibit them) and the museums in turn became monuments to their patrons. Post 1960s corporate sponsors on the other hand, Wallach maintains, in becoming museum patrons have also been, through their presence on boards of trustees, a force for rationalization and expansion. In fact museums have become modelled on their own corporate administrative economies (ibid.).

However, even given the influence and impact of corporate sponsorship on museums' structures and organization over the last 40 years, the Guggenheim project can still be seen to mark a rupture. For it appears that the Guggenheim has itself become the corporation. Its product is artistic intervention that it devises and sets up in suitable venues, which it manages for a fee for up to 75 years (Bradley 1997 p.52). In this light, the Guggenheim's collection can be seen as a 'considerable cultural commodity' that can be capitalized by circulating 'to expand the image of the museum and to facilitate its own growth' (Rectanus 2002, p.180). In the case of the Guggenheim Museum Bilbao, the agreement formed with the Basque authorities is said to be no different from normal franchise contracts (Bradley 1997, p.52).

Several years after the Solomon R. Guggenheim Museum NY was established in 1937, Solomon Guggenheim and the director of the museum, Hilla Rebay, commissioned the architect Frank Lloyd Wright to build a new museum that was to be a 'temple to non objective art'. It was to be 'a temple in spirit, a monument' (Guggenheimguide May-August 2005, p.5). At the time of its opening in 1959 artists feared that the building would be more dominant than the art. They were not wrong with that assessment; nevertheless the building was a success immediately and indeed it is the building, more than the art it shows, that has the greatest familiarity. As Krens says, the 'Frank Lloyd Wright building is the greatest work of the collection' (cited in Solomon 2002). However great building or not the Guggenheim NY have had their financial problems. The museum's endowment has taken a decline since 1998 because Krens has had to persuade the board of trustees to draw from it to cover mounting operating costs $-\$ 9.7 \mathrm{~m}$ in $1999, \$ 13.6 \mathrm{~m}$ in $2000, \$ 13 \mathrm{~m}$ in 2001 (Solomon 2002). It also sold $\$ 14 \mathrm{~m}$ worth of its art collection. A $\$ 20 \mathrm{~m}$ launch of Guggenheim.com intended to make the museum rich was a complete failure (Sadjic 2005). The problems continued to escalate. The Guggenheim's curators were unable to mount their program of exhibitions and there was a major reduction of staff because of costs, but this did not stop Krens from his focus on the next big building project (ibid.).

Thomas Krens says that the way lay open for the Guggenheim to embark on its global venture. In part the 'international perspective' (cited Diamonstein 1994, p.148) was already in place with the Peggy Guggenheim Collection in Venice, willed to the Guggenheim NY in 1979. Plans to merge the two collections were thwarted when the Italian government declared the Peggy Guggenheim Collection a national treasure (Krens interview Charlie Rose Show airdate 3 January 2006). Thus, ten years before Krens took up the position of Director of the Guggenheim Museum, the Guggenheim NY was already managing an off-shore museum. As well, the Guggenheim without direct government support was free to move its collection to wherever its board of trustees agreed. Krens concedes that if the Guggenheim did receive direct government support, there would have been restrictions and sensitivites about 'sharing collections' internationally (cited in Bradley 1997, p.53). By adding the satellite museums to the Guggenheim organization Krens says, 'we start to become pretty formidable as an institution around the world' (ibid.).

Krens believes that creating the Guggenheim satellite institutions was a logical way to achieve 'operational efficiency' for the Guggenheim NY: 'we can improve our program and we can improve our collection' (cited in Diamonstein 1994, p.150). Krens identifies that resources are shared and as the satellite institutions are 'essentially unified under one curatorial organization' (ibid.), curatorial staff and library and research facilities are not duplicated (ibid.). Put another way, Krens says an advantage of the satellite structure is that Bilbao has a 'proportionate increase in exhibition space relative to service space' (Newhouse 2006, p.259). Usually the ratio of exhibition space to other functional spaces in a museum is one to two. With the efficiencies identified at Bilbao ('no duplication of storage, conservation, curators or other essential factors'), the ratio of 
spaces is one to one (ibid.). Emphasizing his point Krens says, 'I can run a larger facility with a smaller staff than anyone else' (cited in ibid.).

The events leading up to the opening of the Guggenheim Museum Bilbao unfold as follows: The Basque authorities in the late 1980s, in their determination to revitalize not just a city but an entire region with $25 \%$ unemployment, came up with a number of building and infrastructure projects. These consisted of the construction of a metropolitan railway, a face-lift to the city airport, a new conference and performing arts centre, a new footbridge crossing the river, development of the riverfront and a new art museum. Contact was made with the Guggenheim Museum precisely at the time the trustees of the Solomon R. Guggenheim Foundation had approved a strategy for responding to their own economic concerns through creating a number of different worldwide cultural centres coordinated from New York. However the contact between the Bilbao authorities and the Guggenheim NY at this time was not simply by chance.

Soon after his appointment to the Guggenheim NY in 1988, Krens completed the restoration and controversial expansion of the Guggenheim NY (architects Gwathmey Seigel Associates) and doubled the size of the Peggy Guggenheim Collection in Venice (architects Leila and Massimo Vignelli). He then went onto establish a Guggenheim museum in SoHo in a cast-iron landmark building (architect Arata Isozaki). As has been often stated, Krens had 'big business strategies' from the start (Suau 1999, pp.12-13). From 1990, rumours of Guggenheim expansion plans in Europe began to circulate. In particular it became known that Krens was talking with authorities in Saltzburg about a possible site there for a Guggenheim museum. A change in the political climate ended the Saltzburg project, despite plans being well underway with architect Hans Hollein. However, even with this major disappointment, Suau notes '...the strategy was clear: Krens wanted to build...' (ibid., p.18).

Much of the Guggenheim's success in Spain was due in a large part to the partnership that Krens formed with Carmen Giménez, who as director of the Centro Nacional de Exposiciones in Madrid, was an influential force in Spanish art and politics. In 1989 Krens offered Giménez the position of Curator $20^{\text {th }}$ century Art at the Guggenheim NY. From then on as a team they set about locating cities in Spain that could be interested in establishing a Guggenheim satellite, or, renting over an extended period some of the Guggenheim's collection. Krens at that time, had acquired 211 Minimalist works for the Guggenheim, from the art collection of Count Giuseppe Panza di Biumo, and was urgently seeking exhibition space for this work. Together Giménez and Krens lobbied Madrid, Barcelona, Seville, Badajoz, Santander, Bilbao. In September 1991 unexpectedly, Bilbao announced that the city was to sign a 'preagreement' to establish the Guggenheim Museum Bilbao (Bradley 1997, pp.48, 50).

As the Guggenheim Museum Bilbao web site puts it, the Basque authorities created the political and cultural and financial backing for the project and the Guggenheim Foundation contributed 'its collections of modern and contemporary art, its programs of special exhibitions, and its experience in international-level museum administration and management' (www.guggenheim-bilbao.es/ingles). The agreement was initially for 20 years with a possible extension up to 75 years (Bradley 1997, p.51). Guggenheim's initial fees were to be a sobering $\$ 20 \mathrm{~m}$. In addition there would be ongoing costs for curatorial and administrative services provided by the Guggenheim NY. In return the Guggenheim NY would curate and organize an agreed number of exhibitions annually from its collection for the duration of the contract. The Basque region and the Biscay province would share equally all the costs incurred in building and operating the museum, including providing $\$ 50 \mathrm{~m}$ over four years to begin to establish a Bilbao art collection-a collection initially identified as 'a new Spanish and Basque collection’ (ibid.).

In October 1997 the Museum opened with two weeks of events. A year later 1,300,000 people had visited the museum and its building costs had been virtually cleared. By 2001 the Bilbao Deputy Mayor assessed that the museum in its four years since opening had already generated $£ 383 \mathrm{~m}$ of economic activity for the city. In its fifth year since opening, the museum was still attracting 852,000 visitors a year (Higgins 2003), 80\% from outside of Spain (Krane 2006).

The building designed by Frank Gehry is spectacular. Respected international curator, Harald Szeemann, says the shiny 'plasticity of the building is like a great burst of sound...' (in Mack 1999, pp. 9-10). Others have spoken of the building as 'a life transforming experience - a pilgrimage and epiphany' (Rectanus 2002, p.182). Herbert Muschamp, New York Times architecture critic, describes it as 'the miracle in Bilbao' (cited in ibid.). Harald Szeemann alert to the complexities of the Guggenheim Bilbao project goes onto say: 'Thanks to Gehry, Janus-faced neo-colonialism has realized the boldest sculptural architecture of our century in Bilbao...' (in Mack 1999, p.10). However despite the triumph of the building, the collection was bought hurriedly and from few sources. Szeemann says it 'is poor with a few exceptions', and further he states:

There are three hideous women's bodies by Dine, bad Warhols, an unsatisfactory LeWitt wall, the usual Kiefers, Schnabels, Basquiats, 
and Burens, and a meagre Beuys collection... (in Mack, 1999, pp. 9-10).

Despite being 'essentially unified under one curatorial organization' (Bradley 1997, p.53), Krens maintains the satellite museums are independent and are not just revolving around New York but provide cross-fertilization (Newhouse 2006, p.259). Nevertheless, specifically for the Bilbao Museum, questions remain. To what extent will the museum be a glamorous warehouse for the Guggenheim NY collection while Bilbao proceeds to fill New York's collection gaps? With the curatorial 'efficiencies' described, to what extent could local regional curatorial practices be developed independently? (Bradley 1997, p.105) To what extent will the Guggenheim NY fulfil its reported commitment to Basque and Spanish contemporary art? (ibid.) Will the Basque and Spanish art collected to date 'be reduced to a trope' within the large Guggenheim collection? (Rectanus 2002, p.180).

It is worth stating that the 'new Spanish and Basque collection' identified by the Guggenheim NY exists as a very small complement of a larger collection of European and American contemporary art (Bradley 1997 p.105). While in 1997 the Guggenheim NY enlarged its own collection by the purchase of four Spanish artists' work, Krens, when questioned that year about the complement of Basque and Spanish art planned for the Bilbao collection, would not be drawn on quotas (ibid.). As well the overall impression of the Guggenheim Museum Bilbao exhibition program of Spanish and Basque art does not look very positive either. In brief, in over ten years there have been 53 exhibitions at the Guggenheim Museum Bilbao. Of these, seven exhibitions have been of Spanish and Basque artists' work and just two exhibitions of Spanish artists' work went from Bilbao to New York (guggeneheim-bilbao.es/ingles/exposiciones/las_exposicio...).

A year before the Guggenheim Bilbao opened, a further agreement was created between the Deutsche Bank and the Solomon R. Guggenheim Foundation. This was to join forces to open a gallery to be called the Deutsche Guggenheim within the Deutsche Bank's central building in Berlin. The agreement is said to be based on the strong existing ties between the Guggenheim NY and Germany, namely, the tracing of the Guggenheim family's origins to Frankfurt, and the recognition of the large number of German artists already represented in the Guggenheim NY collection (Rectanus 2002 p.185). However Rectanus says the alliance had much less to do with family origins or the number of German artists in the Guggenheim collection, and much more to do with 'the coalescence of U.S.-German cultural politics, corporate promotion, and Thomas Kren's globalization strategy' (ibid.). In this light the Gug- genheim in Berlin can be seen to be a U.S. icon commemorating the nature of U.S.-German relations at the close of the Cold War, while at the same time, signalling the formation of a new international Berlin. (ibid., p.186). Rectanus also identifies how this agreement, (believed to be initiated by the U.S. ambassador to Germany at the time), manages to conceal 'the paradoxes and conflicts, both past and present, in the nations' relations' (ibid., p.183)

Hilmar Kopper (1999), a spokesperson for of the Group Board of Deutsche Bank says of the alliance:

Two partners had found each other, both innovative in their own areas, who despite their domestic focus, operated on a global scale...a concept soon emerged that envisaged a unique joint venture between a museum and a company.

\section{And further:}

The global expansion of the Guggenheim Foundation, driven by Thomas Krens, is necessary and understandable given the objective of generating the maximum publicity for outstanding art and making the most effective use of scarce resources.

The Deutsche Guggenheim Berlin program is developed jointly by the Guggenheim curators in New York, and the Deutsche Bank, showing work from both collections as well as exhibitions that travel the Guggenheim circuit. In addition the Deutsche Guggenheim commissions work from artists that they would not have been able to realise without patronage. This is clearly close to Krens' heart. In an article titled 'A Partnership in Patronage' Krens refers enthusiastically to the period of the $16^{\text {th }}$ century in Florence and Rome where the arts were stimulated by generous patronage and artistic production flourished. Krens, in noting the recent decline of government support for the arts in the U.S. says:

As we move into the new millennium, we have to fill this void by re-inventing large-scale patronage within our culture... By joining forces we have been able to achieve a greater purpose in the arts (2000).

The Deutsche Guggenheim opened in November 1997, a month after Guggenheim Museum Bilbao and the international reach of the Solomon R. Guggenheim Foundation had begun in earnest.

In 2000 a Planning alliance was set up between the Solomon R. Guggenheim Foundation, and the two architectual firms, Frank O. Gehry and Associates and Rem Koolhaas' AMO Group. The alliance was 'to undertake feasibility studies for possible 
cultural interventions and projects at strategic locations around the world' (Guggenheim-Hermitage Museum, Press release 27 September, 2000). By this time the Guggenheim Foundation had already produced feasibility studies for museums projects in Saltzburg, Vienna, Osaka and Tokyo (none of which proceeded, and all with a measure of controversy). In the three years after the Guggenheim Museum Bilbao opened there were a further 60 requests for involvement in cultural infrastructure projects from institutions, cities and governments all over the world. The decision was made 'to pool resources and work on those few situations that promise an unusual or extraordinary outcome, one that advances our collective vision of artistic responsibility' (ibid.).

Another project was also developing in 2000. This was the opening of a joint project with the Hermitage Museum and the Solomon R. Guggenheim Foundation in the Venetian Casino Las Vegas. Despite the unusual location for priceless art, the potential 35 million visitors a year to Las Vegas could not be ignored. In the agreement the casino would pay for the costs of building a joint gallery for the Hermitage and Guggenheim and a huge separate gallery for the Guggenheim. The casino would also pay for transport costs bringing exhibitions to Las Vegas and the Guggenheim and the Hermitage would cover the curatorial and organisational costs. The returns from merchandising would go directly to the museums. After costs were covered the casino and the Guggenheim would share entry revenue to the large gallery. Exhibitions would change twice a year. Rem Koolhaas would design the exhibition spaces and it would be completed within the year (Guggenheim Museum press release 20 October 2000).

Following are some of the euphoric statements made at the signing of the agreement by the $\mathrm{Dr}$ Schwydkoi Minister for Culture for the Russian Federation:

...the significance of this project is exceptional for Russian-American cultural relations, first and foremost because this is an equal relationship, the goal of which is to introduce masterpieces from Russian and American museum collections into a worldwide cultural and academic circulation.

Further:

The long-term partnership between the State Hermitage and the Solomon R. Guggenheim Foundation will doubtless bring the humanitarian and cultural collaboration between Russia and the United States to a principally new level (ibid.).

Thomas Krens words at the time were:
The Hermitage is one of the greatest museums in the world...the Guggenheim has one of the most active special exhibitions programs of any museum in the world. By combining our expertise and drawing from two great collections and programs, the Hermitage and Guggenheim working together can create both a brand new range of superb cultural narratives and exhibitions, as well as new facilities and institutions (ibid.).

However despite the unique spaces, the euphoric statements and the 35 million visitors a year, the Guggenheim's financial problems failed to improve. Las Vegas was costing money. The large gallery was closed within 15 months. It was revealed that the Guggenheim paid $\$ 50,000$ a month in rent to the Venetian Casino. \$6m was needed annually to keep the project going (Solomon 2002).

In addition Krens had to face other downsizing. The SoHo annex in New York, which was established 10 years before, had to close in 2001. As well, the elaborate plans for a Gehry designed museum in lower Manhattan were postponed in 2002. Meanwhile the list of planned international branches of the Guggenheim diminished. Taiwan pulled out with serious controversy and the project in Rio de Janeiro (after Krens had revealed publicly that it would bring $\$ 40 \mathrm{~m}$ in fees to the Guggenheim), was declared by the courts to be an illegal agreement (Sudjic January 2005).

There has also been serious questioning of the exhibitions Krens has mounted for the Guggenheim. An exhibition on fashion designer Giorgio Armani (where Armani paid the Guggenheim \$15m for the privilege) was described in the New York Times as 'as surrendering the museum's dignity' (ibid.). Then the exhibition Art of the Motor Cycle, underwritten by Harley-Davidson, was said to be equally commercially driven (interestingly, it proved to draw the largest audience ever for the Guggenheim) (Suau 1999). Nicholas Serota Director of the Tate Modern says: 'The question is to what extent the Guggenheim is still part of the art world. For an artist, it use to be one of the best places to show their work. Now it does the Aztecs, shows which are turning it into a general kunsthalle' (cited Sudjic January 2005). The Aztecs show however was supported by influential Mexican sponsors who were in fact paying for the feasibility study to open a branch of the Guggenheim in the city of Guadalajara (ibid.).

It was the resignation in early 2005 of Peter Lewis, Chairman of the Solomon R. Guggenheim Foundation that revealed the underside of Krens' global vision. Lewis resigned allegedly not only because of the financial position of the Guggenheim (which had been perilous), but interestingly because he believed the Guggenheim's reputation was at stake. 
The Guggenheim's moneymaking ventures seem to have motivated all sorts of exhibitions to be put on the circuit. 'The model of constant growth' Lewis believed hadn't worked (ibid.). Krens had imagined a worldwide network of museums across which to spread exhibition costs. The savings from shared costs turned out to be much less than Krens believed and long tours were disliked greatly by lenders. Critics say Krens has had a driving ambition to expand the Guggenheim into a brand that has stretched resources considerably (ibid.). The Guggenheim has now lost its chief benefactor who had donated $\$ 77 \mathrm{~m}$ to the museum. However within a month of Peter Lewis' resignation Krens and a number of trustees were making a visit to Mexico to check on developments with the feasibility study for the Guggenheim Guadalajara (ibid.).

In 2006, the agreement for the latest expansion of the Guggenheim empire was signed. This is to be the Guggenheim Abu Dhabi (25\% larger than Bilbao) (Vogel 2006), with Frank Gehry the architect and scheduled for completion in 2011. In this project Krens has found a partner who shares his big vision for the future. As he says, 'we have had the good fortune to discover a partner that not only shares our point of view, but expands upon it' (press release Guggenheim museum 8 July 2006). The museum is to be built on the tip (the prize location) of Saadiyat Island (the Island of Happiness), $500 \mathrm{~m}$ off the coastline of the city Abu Dhabi and linked to the mainland by two, ten lane highways. The Guggenheim project is to be part of a cultural plan (developed as an additional source of wealth to non-renewable oil), to establish Abu Dhabi as an international arts centre and tourist destination. Close by, the city of Dubai is developing with pace as an entertainment destination (ski resort with moving mountains, underwater department store etc), but $\mathrm{Abu}$ Dhabi has seen advantages in focusing on culture. Cultural tourists are noted to be older, wealthier, more educated and spend more. It is predicted that Saadiyat Island will be 'the world's largest single arts-and-culture development project in recent memory' (Fattah 2007).

Like in Bilbao, the Guggenheim Abu Dhabi is part of a larger plan. On Saadiyat Island there are to be four additional museums, all defined by 'daring' architecture: a national museum (with a biennale space for 18 pavilions), a classical museum (part of the $\$ 1$ billion arrangement with the Louvre to rent the name, art and expertise, architect Jean Nouvel), a performing arts centre (architect Zaha Hadid) and a maritime museum (architect Tadao Ando) as well as hotels, resorts, golf courses, marinas and accommodation for 125,000 people. In addition talks are taking place with Yale University to create an art school that encompasses art, architecture, dance and drama (ibid.).
The Guggenheim franchise with Abu Dhabi is to operate in a similar way to Bilbao. There would be a down payment (as yet undisclosed), Abu Dhabi would have the use of the brand name for a period of time and the Guggenheim NY would manage the museum's exhibition and educational program, as well as manage acquisitions to develop Abu Dhabi's major collection of contemporary art (press release Guggenheim museum 8 July 2006). The costs of building and operating the museum would be the responsibility of the Abu Dhabi tourist authority. Summing up the agreement Krens says:

They will not take advantage of us, and we don't take advantage of them. It's like a marriage. We're providing a lot, and we will get a compensatory balance, but that's not why we're doing this. It's just a smart thing for everybody (Taylor 2007).

In line with the rhetoric that has surrounded all the Guggenheim global projects, the Abu Dhabi venture is not just about tourism. It is about increasing crosscultural understanding and forging greater understanding between nations. Again there are questions as to how this might occur. In an interview in 1998, Krens gives us some insight to his reading of the concept of 'world culture', which seems to diminish any possibility for an independent identity developing in collections or exhibitions of the satellite museums:

You have to take a look at all this talk of world culture. World culture has dissolved local culture because local cultures by a dialectical process of influence cancel out... Lets project well into the next century. Will such a thing as local cultures exist? You have to come to the conclusion that they will not. And this is not about me liking or not liking local culture and tradition. It is that the forces of culture are out there. I don't believe our objective is to stand in the way of an eroding tradition...W Will there be a culture on a local level? Probably not. Will it be recognizable in terms of traditional characteristics? Probably not either. There will be a world culture out there; there is already a world culture out there (cited in Suau 1999).

Now with a board of trustees comprising of leaders in New York real estate, no one is likely to stand in Krens' way of empire building (Vogel 2005). In June 2005 Krens was still determinedly set on further expansion. He said:

If we don't address Africa, Asia or Russia, we are making a big mistake. How do you do it? With a patronising occasional show on African bronzes from the $14^{\text {th }}$ century? Or do we go [to 
these countries] and get our hands dirty? (Sudjic June 2005).

The Guggenheim global museum project is one model of globalization. There are other models developing between independent museums. One example is the agreement between the Louvre and the High Museum of Art Atlanta, Georgia. A series of nine exhibitions from the Louvre will be displayed in a new wing of the High Museum of Art (designed by Renzo Piano) over three years, for the payment of $\$ 10 \mathrm{~m}$. As part of the agreement the High Museum of Art (which has raised the $\$ 130 \mathrm{~m}$ costs of the museum extension fully through private donations), will give the Louvre advice on business strategies, fun- draising and marketing (Beatty \& Betard 2005). Another example is the Hermitage Museum and the Courtauld Institute of Art London who have formed an alliance to develop joint research, exhibition, publication and conservation programs as well as establishing opportunities for curators from the Hermitage to work in London with their Courtault colleagues. Support for this initiative has come from a major grant from the Edmond J. Safra Philanthropic Foundation (Hermitage Rooms Press release 2003). There is no doubt that money facilitates and drives all of these relationships but perhaps in a manner where art, its content and context remain the core purpose of the exchange.

\section{References}

Beatty E \& Betard D 2005, 'Louvre goes global', The Art Newspaper.com, 25 January, viewed 5 April 2007, www.theartnewspaper.com/news/article.asp?idart $=11673$

Bradley K 1997, 'The Deal of the Century' in Art in America, July pp. 48-55; 105-106.

Charlie Rose Show interview airdate 3 January 2006, viewed 25 March 2007 www.guggenheim.org/press_office.html)

Diamonstein, B 1994, Inside the Art World: Conversations with Barbaralee Diamonstein, Rizzoli International Publications Inc, New York.

Fattah H 2007, 'Celebrity Architects Reveal a Daring Cultural Xanadu for the Arab World', The New York Times, 1 February, viewed 9 February 2007, www.nytimes.com/2007/02/01/arts/design/01isla.html?ei $=\ldots$

Hermitage Rooms Press Release: May 2003, viewed 6 July 2005, www.hermitagerooms.com/about_us/press_release_may2003.html

Higgins C 2003, “Brand wave', The Guardian, 8 May, viewed 23 March 2005, www.guardian.co.uk/arts/higgins/story/0,,951238,00.html

Hooper-Greenhill E 2004, 'Changing Values in an Art Museum Rethinking Communication and Learning', in BM Carbonell (ed.), Museum Studies An Anthology of Contexts, Blackwell Publishing Ltd, Malden, Oxford, Carlton.

Kopper H 1999, '1+1=3', viewed 5 July2005, www.deutsche-bank-kunst.com/guggenheim/alt/english/info/k...

Krane J 2006 'Guggenheim to build in Abu Dhabi', CBS News, 8 July, viewed 23 March 2007, www.cbsnews.com/stories/2006/07/08/ap/entertainment/ma...

Krens T 2000, 'A Partnership in Patronage', viewed 5 July 2005, www.deutsche-bank-kunst.com/guggenheim/alt/english/info/k...

Mack G 1999, Art Museums Into the 21 st Century, Birkhauser, Basel, Berlin, Boston. Introduction by Harald Szeemann. Newhouse V 2006, Towards a New Museum, The Monacelli Press, Inc, New York.

Prior, N 2003, 'Having One's Tate and Eating It: Transformations of the Museum in a Hypermodern Era', in A McClellan, Art and its Publics Museum Studies at the Millennium, Blackwell Publishing Ltd, Malden, Oxford, Melbourne, Berlin.

Rectanus MW 2002, Culture Incorporated Museums, Artists and Corporate Sponsorships, University of Minnesota Press, Minneapolis / London.

Solomon D 2002 'Is the Go-Go Guggenheim Going, Going...', The New York Times Magazine June 30, viewed $9^{\text {th }}$ February $2007 \mathrm{http}: / /$ select.nytimes.com/gst/abstract.html?res=F30C1EFE345B0C738FDDAF0894DA404482\&n=Top\%2fReference\%2fTimes\%20Topics\%2fOrganizations\%2fG\%2fGuggenheim $\% 2 \mathrm{c} \% 20$ Solomon $\% 20 \mathrm{R} \% 2 \mathrm{e} \% 2 \mathrm{c} \% 20$ Museum\&oref=

Spivak GC 2007, 'Politics of culture', International Symposium on New Directions in the Humanities, Columbia University, New York.

Suau JT 1999, 'The Guggenheim Museum Bilbao: Cultural Tourism, Urban Renewal and Political Risk' MA Thesis, American University, Washington (available as an e text).

Sudjic D 2005, 'Is this the end of the Guggenheim dream?' The Observer, 23 January.

Sudjic D 2005, 'There is steel in his soul', The Observer, 19 June, viewed 23 March 2007, www. arts.guardian.co.uk/features/story/0,,1509511.00.html\#article_continue

Taylor K 2007 ‘Abu Dhabi Lures Western Museums', Wired New York Forum, 1 February, viewed 9 February 2007, www.wirednewyork.com/forum/showthread.php? $\mathrm{p}=145369$

Vogel C 2005, 'A Museum Visionary Envisions More', The New York Times, 27 April, viewed 4 May 2005, www.nytimes.com/2005/04/27/arts/design/27kren.html?

Vogel C 2006, 'Guggenheim Foundation and Abu Dhabi Plan Museum There', The New York Times, 9 July 2006, viewed 9 February 2007, www.nytimes.com/2006/07/09/world/middleeast/09gugg.ht...

Wallach A 2003, 'Norman Rockwell at the Guggenheim', in A McClellan (ed.), Art and its Publics Museum Studies at the Millennium, Blackwell Publishing Ltd, Malden, Oxford, Melbourne, Berlin. 
THE INTERNATIONAL JOURNAL OF THE HUMANITIES, VOLUME 5

\section{About the Author}

Susan Ostling

Susan Ostling is a Senior Lecturer Fine Art, Queensland College of Art, Griffith University, Brisbane Australia. As a ceramist she has exhibited widely in Australia, and in Germany, Singapore and South Korea. More recently her practice has shifted to curating exhibitions. Susan is currently completing a $\mathrm{PhD}$ investigating recent changes in curatorial practice focusing particularly on modes of collaboration between curators and artists. 


\section{THE INTERNATIONAL JOURNAL OF THE HUMANITIES}

EDITORS

Tom Nairn, RMIT University, Melbourne.

Mary Kalantzis, University of Illinois, Urbana-Champaign, USA.

EDITORIAL ADVISORY BOARD

Patrick Baert, Cambridge University, UK.

David Christian, San Diego State University, California, USA.

Bill Cope, University of Illinois, Urbana-Champaign, USA.

Mick Dodson, Australian National University, Canberra, Australia.

Hafedh Halila, Institut Supérieur des Langues de Tunis, Tunisia.

Ted Honderich, University College, London.

Paul James, RMIT University, Australia.

Moncef Jazzar, Institut Supérieur des Langues de Tunis, Tunisia.

Eleni Karantzola, University of the Aegean, Greece.

Bill Kent, Monash Centre, Prato, Italy.

Krishan Kumar, University of Virginia, USA.

Ayat Labadi, Institut Supérieur des Langues de Tunis, Tunisia.

Greg Levine, Macquarie University, Sydney, Australia.

Fethi Mansouri, Deakin University, Melbourne, Australia.

Juliet Mitchell, Cambridge University, UK.

Nikos Papastergiadis, University of Melbourne, Australia.

Robert Pascoe, Victoria University, Melbourne, Australia.

Scott Schaffer, Millersville University, USA.

Jeffrey T. Schnapp, Stanford University, USA.

Gayatri Chakravorty Spivak, Columbia University, USA.

Giorgos Tsiakalos, Aristotle University of Thessaloniki, Greece.

Siva Vaidhyanathan, New York University, USA.

Hortensia Beatriz Vera Lopez, University of Nottingham, UK.

Chris Ziguras, RMIT University, Australia.

Please visit the Journal website at http://www.Humanities-Journal.com for further information:

- ABOUT the Journal including Scope and Concerns, Editors, Advisory Board, Associate Editors and Journal Profile

- FOR AUTHORS including Publishing Policy, Submission Guidelines, Peer Review Process and Publishing Agreement

SUBSCRIPTIONS

The Journal offers individual and institutional subscriptions. For further information please visit http://ijh.cgpublisher.com/subscriptions.html. Inquiries can be directed to subscriptions@,commongroundpublishing.com

INQUIRIES

Email: cg-support@,commongroundpublishing.com 
